\title{
THE ETHICAL DOCTRINES OF ANCIENT SANSKRIT TEXTS AND THEIR IDENTIFICATION IN THE PRINCIPLES OF DHAMMAPADA
}

\author{
Dr. Binima Buzarbaruah
}

\begin{abstract}
The Dhammapada, which is one of the best known Buddhist scriptures, has a great ethical value. The path that leads to real happiness is very well depicted in this work. The teachings of Dhammapada are very much similar to the ethical principles found in ancient Sanskrit texts which lead to salvation. In this paper an attempt has been made to bring certain principles of the ancient Sanskrit texts to light which have their identification in the doctrines of the Dhammapada.
\end{abstract}

Human life is regarded as the blessing of God. One's life becomes happy and peaceful only when he leads his life with righteousness. Teachings of the scriptures of every religion show the people, the way of an ethical living. In India, the ancient Sanskrit scriptures are the very essence and storehouse of various ethical doctrines leading to an ideal life. Amongst the Buddhist religious scriptures, the Dhammapadais one which deals mainly with the ethical way of life. Following the principles of both the Sanskrit scriptures and the Dhammapada, one of the most popular Buddhist texts, a man is able to attain the real happiness and ultimate goal of his life.

The spiritual wisdom is not possible if the evil is not purged. The ancient Sanskrit texts have laid emphasis on the shedding of all 
evils of a man to gain wisdom. It is the teaching of the Upanisad that if one does not shed evil, he cannot expect to obtain freedom. To cleanse one's nature for reaching the goal is compared to a clean mirror which is only able to reflect an object. The self within the body is said to be attainable only by truth, austerity, right knowledge and practice of chastity. ${ }^{1}$ According to the Śrimadbhagavadgit $\bar{a}$, there are two types of beings who have been created in the world. Those are divine and demonic. The demonic beings do not have knowledge about the way of action and also they are devoid of the qualities like purity, truthfulness, renunciation and so on.

dvaubhūtasargauloke'smindaivaāsuraeva cal

daivovistaraśahproktaāsuraimpārtha me șrnu//

pravrttim ca nivrttim ca janānavidurāsurāh/

naśaucaìnna $\bar{a}^{\prime}$ picā'cāronasatyamiteșuvidyate/ $/ 2$

As the ancient Sanskrit scriptures instruct every person to abstain from the wrong doing, in the Dhammapada also evil is completely prohibited. One is instructed to restrain their minds from that which is evil. It is stated there that once evil is done, it should not be repeated. With the accumulation of evil, pain is generated. According to this scripture, a jar is filled with water only with the help of water drops. Likewise, a fool fills himself with evil, acquiring evil bit by bit. There is no such place where one can stay and escape evil, even not up in the air, in the middle of the sea, going into a cleft in the mountains and also nowhere on the earth. It also declares that when one is free from all impurities and becomes unblemished there is no fear of rebirth. The Dhammapada declares evil deeds as the real impurities. It also suggests the way to remove such impurities. The wise man, according to this text, makes himself free from the impurities whatever acquired, just as a silver smith step by step blows away all the impurities of moulted silver. ${ }^{3}$ 
To lead a sacred life desirelessness of the mind is very much necessary. True knowledge takes one to the place where there is the end of the desire. The Bṛhadäranyaka Upanișad declares that as is one's desire, so is his will. As is his will, so is his deed he does and whatever deed he does that he attains.

sayathākāmobhavati, , tat kraturbhavati,

yatkraturbhavati, tat karma kurute, yat karma kurute, tat abhisampadyate.

It also states that the man who does not have desire or who is without desire, he is not to come again to this world. ${ }^{4}$ The Bhagavadgit $\bar{a}$ also has rightly stated that having enjoyed the heaven, the people enter the world of mortals, when their merit is diminished. People desirous of enjoyment have to fall in the cycle of birth and death. ${ }^{5}$ The Dhammapada also instructs that one should cut down the forest of desires instead of forest of trees. According to this from the forest of desire there only comes danger and fear. ${ }^{6}$

\section{Vanajchindatha ma rukkhajvanato \\ Jayatebhayaj \\ Chetvavanaj ca vanathaj ca nibbana \\ Hothabhikkhave}

To reach the goal it is very essential to maintain the purity of body, mind and speech. The Bhagavadgit $\bar{a}$ declares three kinds of penances viz. the penance of body, the penance of mind and the penance of speech. That is called the penance of body where there is the worship of gods, teachers and wise persons and also where purity, honesty, continence and non violence have been maintained. Moreover, self satisfaction, gentleness, silence, self control are regarded as the penance of mind. The utterance of words which does not produce any offence, which is truthful, pleasant and beneficial, is stated as the penance of speech.

Devadvijaguruprajșrpūjanamiśaucamārjavam/

Brahmacaryamahimsā ca śarīramitapa ucyate// 


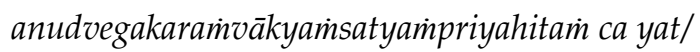
svādhyāyābhyāsanai்caivavāimmayam tapa ucyate// manahprasādahsaumyatummaunamātmavinigrahal bhavasamiśuddhirityetattapomānasamucyate / / 7

With the help of these three penances illumination is produced which is the immediate condition of salvation. In regard to the speech, body and mind the Dhammapada is also of the same view that these are to be guarded and well restrained. One should purify these three courses of actions and win the path realised by the sages. ${ }^{8}$ This is also stated by this text firmly that those people only can be called as enlightened ones who have restrained their body, mind and speech.

Greed, restlessness, longing etc. are the very obstructions in the spiritual path resulting from passion. It is the declaration of the Bhagavadgit $\bar{a}$ that these are grown where there is the increase of the mode of rajas i.e. passion. It is also stated that the fruit of passion is pain and sorrow. ${ }^{9}$ Similar idea is declared by the Dhammapada that it is the grief and fear that are born out of passion. ${ }^{10}$

Piyatojayatisokopiyatojayatibhayaj

Piyatovippamuttassanatthisoko

Kutobhayaj

So, in both the scriptures the people are instructed to be free from passions, the very cause of one's sorrow.

Another declaration of the Bhagavadgit $\bar{a}$ is that one is attached to happiness by the quality of goodness. The mode called goodness being pure, causes illumination. It is associated with happiness and knowledge. ${ }^{11}$ The nature of good and its consequence is declared in the same way in the Dhammapada, that the world holds that person as dear and good who is excellent in virtues, who is truthful and who performs his own duties. When one does good deeds and departs from this world to the world beyond, then his good leads him to that path as it is done by one's near and dear one. ${ }^{12}$ 
It is very essential for a man to have self control for leading a pious life. Man should be the master of their senses but not servants. It is the instruction of the Bhagavadgit $\bar{a}$ to withdraw the senses from the sense objects. In this case he should be like a tortoise as a tortoise draws its limbs within the shell. In this great text Arjuna is found admitting his incapacity to realise the advice given by Lord Kṛṣna because of the fickleness of the mind. This fickle mind is difficult to control like wind. Kṛnna told that every hard object can also be attained through self control. The restless mind according to Kṛṣna can be controlled by constant practice and non attachment. ${ }^{13}$

The Dhammapada also has admired a person whose senses have been steadied. It is stated that who has controlled his senses like the horses, well trained by the charioteer, even devas adore him. ${ }^{14}$

yass'indriyanisamathajgataniassa

yathasarathanisudanta

painamanassaanasavassa deva pi

tassapihayantitadino

The nature of the mind is very nicely shown in the Dhammapada that it quivers, wavers and is difficult to guard. To hold it in check the sages make it straight like a Fletcher who straightens the shaft of an arrow. ${ }^{15}$

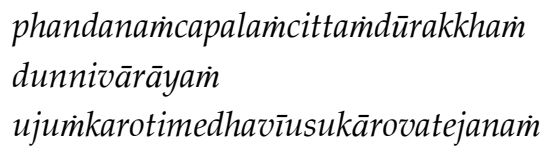

It is also stated that the mind which is protected brings ease. Anill directed mind is stated as worse than an enemy's act to an enemy. ${ }^{16}$

Irrespective of the age whether old or young, the greatest lawgiver Manu in his Manusmrti has declared a person to be wise. It is because; a true human personality can be recognised only by the knowledge acquired by him. To him white hair is not a symbol 
of one's seniority. Because of having knowledge a young person also stated to be old. ${ }^{17}$ The Dhammapada also is of the same opinion in this regard that a head of grey hair does not signify one as an elder. Instead, he should be called as an old fool. But younger in age, he is an actual elder who is enlightened with the qualities like truthfulness, righteousness, gentleness and self control. ${ }^{18}$

There are many negativities which are noticed in a human conduct like attachment for objects, passion, anger, delusion etc. The Śrimadbhagavadgìta and the Dhammapada are in the same tune in regard to these and state these negativities as the destroyer of a person. The Bhagavadgit $\bar{a}$ declares that if a man contemplates the objects of sense, attachment to them is produced. From attachment passion is developed and from passion anger arises. Delusion arises from anger and from delusion there is the loss of remembrance. When there is the loss of memory, intelligence is destroyed and when one is devoid of intelligence, he perishes. ${ }^{19}$ The Dhammapada compares passion, anger and delusion to fire, seizure and snare respectively, each of which brings a person to downfall. ${ }^{20}$

The main purpose of the life of every human being is to reach his ultimate goal. To fulfil this purpose ethical living is very essential for him. In Buddhism, Dhammapada is a scripture where different such keys are available by which one can get rid of difficulties and sufferings and attain the real happiness. Various principles present in the Dhammapada are found as similar to those of different Sanskrit texts from which the main intention of both i.e. to direct the path of an ethical living, can be well realised.

\section{References :}

1. Kathopanișad, 1.2.2-3; ŚvetāsvataraUpanișad 2.14-15; Muṇdaka Upanișad 3.1.5

2. Śrīmadbhagavadgìtā $16.6,7$

3. Dhammapada, $122,127,238,242$ 
4. Bṛhadāranyaka Upanișad, 4.4.5, 6

5. Śrīmadbhagavadgìtāa, 9.21

6. Dhammapada, 283

7. Śrìmadbhagavadgìtā, 17.14-16

8. Dhammapada, 281

9. Ibid, $14.12,16$

10. Ibid, 212

11. Śrimadbhagavadgītā, 14.6

12. Dhammapada, 217

13. Śrīmadbhagavadgītā, $2.58 ; 6.34$

14. Dhammapada, 94

15. Ibid, 33

16. Ibid, 42

17. Manusmrti, 2.156

18. Dhammapada, 260

19. Śrīmadbhagavadgītā, 2.62 